\title{
DEFORMATION AND STABILITY ANALYSIS OF SHALLOW THIN-WALLED CONICAL SHELLS IN CASE OF COMBINED LOAD OF UNIFORM PRESSURE AND CONCENTRATED IN POINT FORCE USING ANSYS SOFTWARE ENVIRONMENT
}

\author{
${ }^{1}$ Bessmertnyi Y. O., post-graduate student, \\ yaroslavbessmertnyi@gmail.com, ORCID: 0000-0002-6884-0925 \\ ${ }^{1}$ Krasovsky V. L., Doctor of Engineering, Professor, \\ stmehanika@gmail.com, ORCID: 0000-0003-0647-3880 \\ ${ }^{1}$ Prydniprovs $k a$ State Academy of Civil Engineering and Architecture \\ 24a, Chernyshevsky street, Dnipro, 49600, Ukraine
}

\begin{abstract}
The article is devoted to the study of the deformation and stability process of shallow thin-walled elastic conical shells in case of non-homogeneous stress-stain state due to the action of combined load of external uniform normal pressure and force applied in the point for uniform immobile hedge border fixation. Such a type of loads in reality may be corresponded to the action of snow layer in certain region accordingly to the territory map in ДБН В.1.2-2:2006 "Loads and influences. Terms of designing" with change №1, and action of construction or human weight which may be situated on the surface of conical shell.

A study of deformation and stability process has been conducted with help of numerical modelling using software ANSYS environment which effectiveness in applying to solve problems of such type has been approved on the international level. A model of shallow conical shell has been made using finite-element SHELL 281 that let us to obtain not only symmetric by axe of rotation form of instability but also asymmetric form of instability. Numerical modeling has been conducted for two types of computations - either linear Eigen-buckling computation with determination of critical pressure qcr and corresponding to it buckling form or geometrically nonlinear computation of deformation with determination of limit pressure value qlim and corresponding to it buckling form. Obtained results have been compared to the computational load values that may be observed on the territory of Ukraine.

Detailed analysis of impact of every component of combined load on the shell's bearing capacity has been made for construction in total. In every case of computation, external uniform normal pressure has been main cause of buckling whereas applied in the point force was the fact the critical and limit pressure values have been changed. In these cases, point of force application was moved in space along the origin of the cone in direction from the top to the base of shell. Detailed analysis of impact of force applied in the point on the total buckling form has been done for different positions of application point along the origin of shell. Force application points that have the major impact on buckling form have been mentioned in the article.
\end{abstract}

Keywords: shallow conical shell, combined load, ANSYS.

Introduction. Thin-walled shallow closed conical shells have reached widespread appliance in petroleum, industrial, aerospace and civil construction due to the simplicity of their production and reliability of structure. Shallow conical shells may play role of either roof element of silo or element of reservoir bottom. Subject of shallow conical shells is well investigated but there is a number of questions to solve, for example, deformation and stability of such shells in case of combined load. Relevance of these subject is testified by this fact nowadays.

Analysis of last investigations and publications. For the last decade, a large series of shallow thin-walled closed conical shells of small scale have been carried out in wide range of geometrical properties. Geometrical properties of shallow conical shells lied in next ranges: thickness parameter was $\mathrm{R} / \mathrm{h}=100 \ldots 2000$ and angle of origin incline compared to the shell base was $\alpha=0 \ldots 20^{\circ}[1,2]$. The deformation and stability investigation has been carried out either in laboratories during physical experiments or in conditions of numerical environment of software ANSYS [1-3]. Input data for every

Bulletin of Odessa State Academy of Civil Engineering and Architecture, 2020, no. 79, page 27-33 
experiment and numerical modeling consisted in next. Shell's border fixation has been implemented as immobile and mobile simply-supported or fixed fixation where border displacement allowed in surface of shell base (for mobile fixation). Load type - external normal uniform pressure. Thickness parameter $\mathrm{R} / \mathrm{h}$ and angle of origin inclination have been already noticed in the article above.

The dependencies of values of applied to the shell surface pressure from displacement of pike point $w$ related to the shell thickness $h$ have been made during numerical investigations. Analyzing obtained graphs "q-w/h", the value of limit pressure $\mathrm{q}_{\text {lim }}$ has been obtained that shows us the moment of shallow conical shell stability losing with spasmodic transition to the adjacent equilibrium state known as "inversion".

The results of numerical study have been compared to the result of physical experiments and good degree of accordance between them has been obtained. It is indicated by obtained results that software ANSYS may be used for further investigations of deformation and stability of shallow thin-walled shells in more complicated exploitation conditions like combined load of external normal pressure and applied in the point force for uniform border fixation.

Note that problem of shell instability due to the action of combined load (normal pressure, force and momentum of torsion) has been analyzed by Grishak et al [4]. This investigation has been carried out for non-shallow conical shells which origin inclination angle was $\alpha>20^{\circ}$. The task was simplified to the solution of integral singular normal differential equation of sixth degree with variable coefficients. Different solutions obtained due to the use of phase integrals method (VKB), hybrid VKB-Galerkin method and finite difference method have been compared in the article. The advantages of asymptotic hybrid approach to solve equations of such type have been presented in work [4]. The rational relation of thicknesses to the Young's modulus of three-layered shell has been analyzed for case when the structure was the most stable for load type discussed earlier. The problem of limit surfaces construction that separate fields of stability and instability has been analyzed. Also, the effectiveness of such three-layered structures as force elements working on stability has been approved [4].

Formulation of the problem. Based on the foregoing, it is possible to make the conclusion that investigated shells were in conditions of homogeneous in circumferential stress-strained state (SSS) on the stage corresponded to the pre-critical ascending branch of equilibrium states of " $\mathrm{q}-\mathrm{w} / \mathrm{h}$ " dependency. Homogeneous in circumferential direction SSS is an important factor for modeling and analysis of shallow conical shell stability but, at the same time, in real conditions such situations are unlikely due to the presence of material or geometry imperfections and presence of different load combinations $[1,3]$. According to the foregoing it is important to investigate the deformations and stability of shallow conical shell in case of non-homogeneous SSS caused by the action of simultaneous action of either normal external uniform pressure or force applied at the point. General recommendations how to calculate non-shallow conical shells are given in [5] but these recommendations can't be applied for shallow conical shell with origin inclination angle smaller than $\alpha \leq 20^{\circ}$.

The solution of this problem using analytical methods may lead to the large amount of time investment comparing to the numerical modeling using software environment ANSYS. This fact determines the incompleteness of shell investigation in historical context but may be complete by use of modern informational technologies.

The aim and the tasks. The aim of investigation consists in detailed analysis of deformation and stability of thin-walled shallow conical shells simply-supported border and non-homogeneous SSS caused by the simultaneous action of external normal uniform pressure $q$ and applied in the point force $\mathrm{F}$. In this case, the value and range of external pressure q extends over the entire surface of the shell, and the force F can only change its position in space along the forming shell in the direction from the top to the base. The goal is also to create a numerical model of a shallow conical shell in an ANSYS software environment, which will allow an analysis of the behavior of the shell under these conditions, and, in fact, to evaluate the applicability of ANSYS software to solve problems of this type.

The purpose of the study is as follows:

Bulletin of Odessa State Academy of Civil Engineering and Architecture, 2020, no. 79, page 27-33 
1) to study the process of deformation and stability of a series of shells under the condition of a homogeneous simply-supported edge of the shell and the action of force applied at a point that can change its position in space but not in time from the top to the base of the shell, and the vector of force action is parallel to the axis of rotation of the shell in the direction from the top to the base of the shell;

2) to study the process of deformation and stability of a series of shells with the same conditions of fastening, but in case of simultaneous action of external normal pressure and applied at a point force under the same conditions for force;

3) evaluate the role of each component of the combined load on the shell deformation process and their effect on the overall bearing capacity of the considered shells.

Materials and methods of research. Numerical analysis of the stability problem of elastic closed conical shallow shells was carried out by modeling and calculating over a wide range of geometry changes in the ANSYS software environment. The ratio of the radius of the shells base to their thickness was $\mathrm{R} / \mathrm{h}=100 \div 500$. The angle of inclination of the cone origin to the plane of its base was $\alpha=4$ and $10^{\circ}$, the thickness of the shells $h=4 \mathrm{~mm}$. The material of the shells is alloy steel (X18H9n, Young's modulus E $=2 \times 10^{5} \mathrm{MPa}$; Poisson's ratio $-v=0.3$; conditional yield strength $\sigma_{02}=800 \mathrm{MPa}$ ). The loading was presented as simultaneous action of uniformly distributed over the entire surface of the cone external homogeneous normal pressure (q) and the force applied at the point (F). The boundary conditions of the shells in the calculation were taken as simply-supported fixation (displacements along $\mathrm{X}, \mathrm{Y}$ and $\mathrm{Z}$ axis are constrained). The upper part of the shell is truncated and has a circular horizontal plate. The radius of the upper plate is chosen so that the bearing capacity of the shell does not differ from the bearing capacity of the non-truncated hollow conical shell by a value greater than $0.5 \%$, resulting in a ratio of $1 / 20$ of the radius of the truncated part of the cone to the radius of the base. The thickness of the plate covering the truncated portion is equal to the thickness of the shell. The connection of the plate to the shell is considered as rigid.

At combined load, five main points of force application to the surface of the shell are considered: at the top of the shell; at the edge of a circular plate at the top of the shell; at a distance of $0.25 \mathrm{R}$ from the top of the shell (where $\mathrm{R}$ is the radius of the base of the shell); at a distance of $0.5 \mathrm{R}$ from the top of the shell; at a distance of $0.75 \mathrm{R}$ from the top of the shell. In addition to the main points, additional force points are introduced to increase the detail of the dependence of the critical force $F_{c r}$ at the point at which it is located on the surface of the shell. Schemes of loading conical shells are shown on Fig.1 with a combination of an external homogeneous normal pressure q (left diagram) and an applied point F (right diagram), the point of application of which could change its place in space.

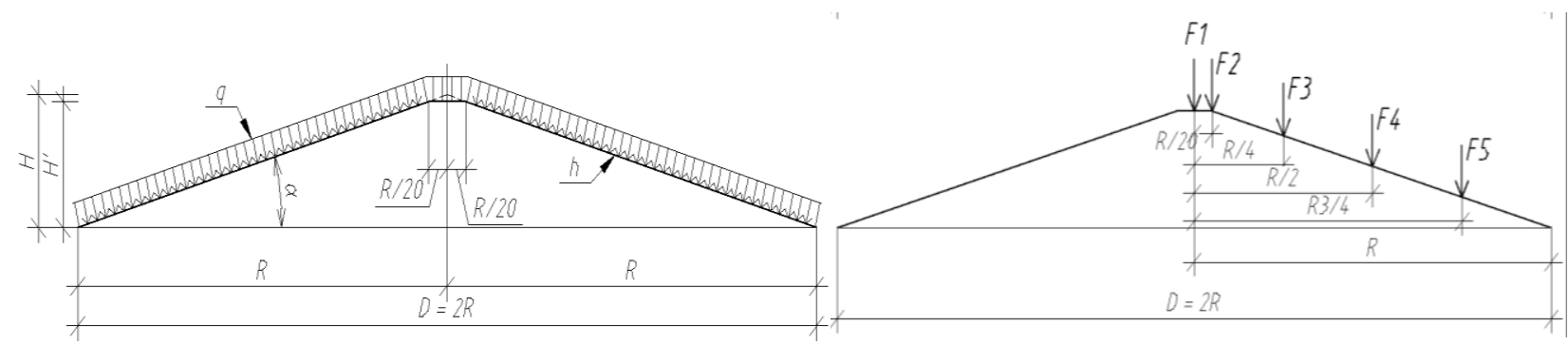

Fig.1. Computational model of shallow conical shell in case of combined load - external normal uniform pressure and applied at point force. F1-5 - point of force application

During the numerical simulation of the behavior of the shallow conical shells under combined loading, two types of calculations were carried out - linear bifurcation calculation with determination of critical pressure values $\mathrm{q}_{\mathrm{cr}}$ or $\mathrm{F}_{\mathrm{cr}}$ and corresponding buckling shape of shell (problem 1) and calculation of geometrically non-linear deformation problem with determination of limiting pressure $\mathrm{q}_{\text {lim }}$ values or the force $\mathrm{F}_{\mathrm{lim}}$ and buckling shape corresponding to them (problem 2).

Finite element (FE) SHELL 281 has been used in two types of computation. FE SHELL 281 (Fig. 2, a) has 8 node point with 6 degrees of freedom at every node. FE-model of shallow conical shell is shown on the Fig.2, b. 


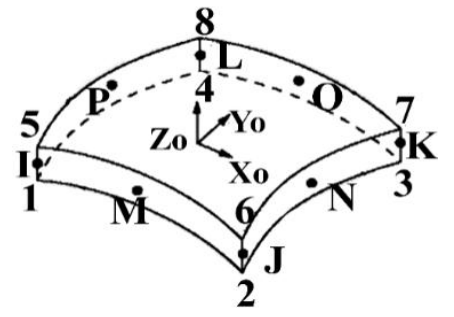

a)

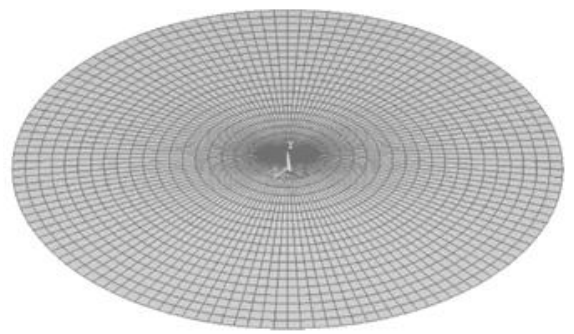

b)

Fig. 2. Parts of FE-model of shallow conical shell: a - finite element SHELL 281; b - FE mesh of shell model

The application of the SHELL $281 \mathrm{CE}$ to the creation of a shallow conical shell model and its subsequent calculation when loaded with a combination of external uniform pressure and applied at a point force allows to obtain a buckling form that is not only symmetrical about the axis of rotation but also asymmetrical.

The total number of elements in the FE model of the shallow conical shell is $\mathrm{N}=4096$. This number of elements was chosen on the condition that further condensing of the finite element mesh does not lead to such changes in the bearing capacity of the shell, which is more than $0.5 \%$ from the previous step. From the point of view of saving the time spent on machine work, such an approach gives a clear effect when performing geometrically nonlinear calculation of deformation of shallow conical shells.

The FE-model of shallow conical shell has been created in software environment ANSYS in four steps: 1) the origin of the cone has been created on the surface the $Y$ axis belongs to; 2) geometrical model of shallow conical shell has been made by rotation of origin around the $\mathrm{Y}$ axis for $360^{\circ}$ with creation of four equal segments; 3) boundary conditions determination with limitation of point displacement along $\mathrm{X}, \mathrm{Y}$ and $\mathrm{Z}$ axis; 4) creation of finite element mesh with total element amount $\mathrm{N}=4096$.

Research results. The results of numerical modeling of deformation and stability of shallow conical thin-walled shells were compared with common types of loads, which are considered in regulatory documents [6]. In reality, the combined load of external uniform pressure and the force applied at the point may have the following form - the pressure component is the result of the action of the weight of the snow cover, and the force applied at the point - by the presence of any structure by the type of tube or antenna attached to the surface of the conical shell, or matches the weight of the person with the snap.

As a result of the linear bifurcation calculation of the shallow conical shells for five cases of concentrated force, we have the following: there is a gradual decrease in the bearing capacity of the shallow conical shell as the point of application of force changes it position from the apex to the base along the forming one has been observed. The gradual change of the point of application of force causes the load carrying capacity of the shell to drop from $3.5 \mathrm{kPa}$ to $2.29 \mathrm{kPa}$. But despite the $34.6 \%$ drop in the critical pressure value, the load-bearing capacity of the shell remains ensured when loading the estimated weight of the snow cover and the weight of the person with the equipment [6]. The estimated weight of the snow cover corresponds to the value of pressure for Vth snow region and is equal to $\mathrm{S}_{0}=$ $1.8 \mathrm{kPa}$ whereas the estimated weight of the person with the snap is $F_{\text {human }}=1.2 \mathrm{kN}$. The values of the critical pressure $\mathrm{q}_{\mathrm{cr}}$ depending on the location of the point of application of force $\mathrm{F}$ are shown in table 1 .

Table 1 - Buckling shapes for shallow conical shells $\left(\mathrm{R} / \mathrm{h}=400, \alpha=4^{\circ}, \mathrm{h}=0.005 \mathrm{~m}\right)$ in case of combined load of uniform normal pressure $\mathrm{q}$ and force $\mathrm{F}$

\begin{tabular}{|c|c|c|c|c|c|}
\hline Buckling shape & & & & \\
\hline$q^{c r}, k P a$ & 3.501 & 3.501 & 3.448 & 2.558 & 2.289 \\
\hline $\begin{array}{c}\text { Point of force } \\
\text { application }\end{array}$ & $\mathrm{F} 1$ & $\mathrm{~F} 2$ & $\mathrm{~F} 3$ & $\mathrm{~F} 4$ & $\mathrm{~F} 5$ \\
\hline
\end{tabular}


Analyzing the buckling forms presented in Table 1, the degree of influence of the force application point on the overall bearing capacity of the shell increases as the point moves along the origin from the top to the base of the shell. When the force is located in the region of the points F1-3, the shape of the stability loss remains axisymmetric with the same number of waves in the circumferential direction and a certain redistribution of the conditional amplitude of the waves, which is to increase the magnitude of the waves emission in the region close to the point of force application and to reduce the waves from the opposite side. When the force is located in the area of points F4-5, the buckling shape changes significantly according to the following model - the nature of the buckling shape of the transforms to the asymmetrical according to the rotation axis of the shell but becomes symmetrical with according to the cone origin on which the point of force application is located; the total number of waves is halved (in this series of shells); the amplitude of the buckling waves in the region of the point of force application in accordance with close waves is greatly increased.

As a result of geometrically nonlinear calculation of deformation of the shallow conical shells, the behavior of the considered shells under the action of combined loading with normal homogeneous pressure (snow cover) and concentrated at a point force (a man with a snap) was performed. The main criterion for calculation is that the shell must not lose stability when the calculated value of the combined load is reached, and the maximum equivalent stresses in the shell should not exceed the conditional yield strength of X18H9n steel (800 MPa).

According to the obtained data in Table 2, maximal equivalent stress values are lower than conditional yield strength values and maximal displacements of shell surface are smaller than one and half of shell thickness. Shallow conical shell does not lose stability when it reaches the calculated values of combined load.

Table 2 - Maximal von Mises stress values for shallow conical shells $(R / h=400, R=2 \mathrm{~m})$ in case of loading by external normal pressure $\mathrm{q}_{\text {snow }}$

\begin{tabular}{|l|l|l|l|l|l|l|l|l|l|}
\hline$R / h=400$ & $q_{\text {snow }}, k P a$ & 0.8 & 1.0 & 1.2 & 1.4 & 1.6 & 1.8 & $q^{\text {lim }}, k P a$ & $q^{c r}, k P a$ \\
\hline \multirow{2}{*}{$\sigma_{\text {Mises, }} M P a$} & $\alpha=10^{\circ}$ & 1.77 & 2.21 & 2.65 & 3.09 & 3.53 & 3.98 & 38.7 & 14.7 \\
\cline { 2 - 10 } & $\alpha=4^{\circ}$ & 4.24 & 5.30 & 6.36 & 7.42 & 8.48 & 9.54 & 5.92 & 3.59 \\
\hline
\end{tabular}

Conclusions. According to the results of numerical study of deformation and stability of shallow thin-walled conical shells in the ANSYS software environment, the following conclusions can be made:

1. A numerical model has been created to analyze the deformation process and the stability of shallow conical shells under the action of combined loading, represented as a pair of factors external normal homogeneous pressure $\mathrm{q}$ and applied at point force $\mathrm{F}$. This model allows to study the behavior of shallow conical shells in conditions approximate to real, corresponding to the load case of a shallow conical shell (acting as a force element of the structure) by the action of the snow cover and the weight of the person or structure.

2. The process of deformation and stability of shallow thin-walled conical shells under the action of combined loading in linear and geometrically nonlinear formulation in the ANSYS software environment has been investigated. Obtained values of the bearing capacity of the shallow conical shells indicate that the shells may be in operation under the mentioned foregoing load conditions without the risk of loss of stability. It also explores the capabilities of ANSYS software which allows the use of this software to solve these problems by numerical simulation.

Recommendations for further research. Further studies of deformation and stability of shallow thin-walled shells at non-homogeneous SSS (in case of combined load action) are recommended for more complicated cases - the presence of moment at the top of the shell or at the number of forces $\mathrm{N}>2$ applied along the forming. Additional is the study of the stability of the shallow conical shells with a symmetric (relative to the axis of rotation) arrangement of forces.

\section{References}

[1] A.G. Karasev, "Initial imperfection influence on the buckling load of closed elastic isotropic shallow conical shells", Mathematics and Mechanics of Solids, vol. 21, no. 4, pp. 
444-453, 2016. https://doi.org/10.1177/1081286514526082.

[2] V.L. Krasovsky, A.G. Karasev, "Properties of numerical solution of the deformation and stability problem in shallow conical shells under external pressure", Roads and Bridges, vol. 15, pp. 117-135, 2016.

[3] Y.O. Bessmertnyi, "Deformation and stability of thin-walled shallow conical shells under external pressure and periodically discrete border fixation", Bulletin of Zaporizhzhia National University: Collection of scientific works. Physical-mathematical works, no. 2, pp. 14-19, 2017.

[4] V.Z. Grishak, D.D. Grishak, N.M. D'yachenko, "Effektivnoe priblizhennoe analiticheskoe reshenie zadachi ustojchivosti trehslojnoj konicheskoj obolochki pri kombinirovannom nagruzhenii", Zhurnal «Matematichni metodi ta fiziko-mehanichni polya», vol. 61, no. 3, pp. 63-77, 2019.

[5] DBN V.2.6-198:2014. Stalevi konstrukciyi. Normi proektuvannya. Kiyiv: Derzhavne pidpriyemstvo «Ukrarhbudinform». 2014.

[6] DBN V.1.2-2:2006. Navantazhennya i vplivi. Normi proektuvannya. Zmina № 1. Kiyiv: VAT «Ukrdniproektstalkonstrukciya im. V. M. Shimanovskogo». 2007.

\title{
АНАЛІЗ ДЕФОРМУВАННЯ ТА СТІЙКОСТІ ПОЛОГИХ ТОНКОСТІННИХ КОНІЧНИХ ОБОЛОНОК ПРИ КОМБІНОВАНОМУ НАВАНТАЖЕННІ РІВНОМІРНИМ ТИСКОМ ТА СКОНЦЕНТРОВАНОЮ У ТОЧЦІ СИЛОЮ У СЕРЕДОВИЩІ ПРОГРАМНОГО КОМПЛЕКСУ АNSYS
}

\author{
${ }^{1}$ Бессмертний Я.О., аспірант, \\ yaroslavbessmertnyi@gmail.com, ORCID: 0000-0002-6884-0925 \\ ${ }^{1}$ Красовський В.Л., д.Т.н. професор, \\ stmehanika@gmail.com, ORCID: 0000-0003-0647-3880 \\ ${ }^{1}$ Придніпровськя державна академія будівництва та архітектури \\ вул. Чернишевського, 24а, м. Дніпро, 49000, Україна
}

Анотація. Досліджено процес деформування та стійкості пологих тонкостінних конічних пружних оболонок при неоднорідному напружено-деформованому стані, обумовленому дією комбінованого навантаження зовнішнім нормальним однорідним тиском та прикладеною у точці силою при нерухомому шарнірному закріпленні краю оболонки. Даний тип навантаження в реальних умовах може відповідати дії снігового покрову в певному районі відповідно до карти районування територій у ДБН В.1.2-2:2006 «Навантаження та впливи. Норми проектування» зі зміною №1, та дії ваги конструкції або людини, що можуть знаходитися на поверхні конічної оболонки.

Дослідження деформування та стійкості пологих конічних оболонок виконано шляхом чисельного моделювання у середовищі програмного комплексу ANSYS, ефективність застосування якого вже була підтверджена на міжнародній науково-практичній арені. Модель пологої конічної оболонки була створена з застосуванням чотирикутного скінченого елементу SHELL 281 з вісьмома вузловими точками, що дозволило отримати не лише симетричну відносно осі обертання форму втрати стійкості, але й несиметричну. У ході виконання чисельного моделювання проводилося два типи розрахунків - лінійної задачі втрати стійкості (біфуркація) з визначенням критичного тиску q втрати стійкості, та задачі геометрично нелінійної деформації з визначенням граничного тиску $\mathrm{q}_{\lim }$ та відповідної йому форми втрати стійкості. Отримані значення несучої здатності оболонок порівнювались 3 розрахунковими значеннями навантажень, які можливо спостерігати на території України.

Проведено аналіз впливу кожного елементу комбінованого навантаження на несучу здатність оболонки в цілому. В кожному випадку розрахунку саме рівномірний нормальний зовнішній тиск був вирішальним фактором втрати несучої здатності оболонки, тоді як зміна точки прикладання сили лише впливала на величину критичного та граничного навантаження при переміщенні сили вздовж утворюючої конуса у напрямку від вершини

Bulletin of Odessa State Academy of Civil Engineering and Architecture, 2020, no. 79, page 27-33 
оболонки до iï основи. Проведено аналіз впливу точки прикладання сили на загальну стійкість оболонки, зокрема на характер утворення та розподілу хвиль при біфуркації, їх відносні розміри та області розподілення хвиль. Вказані області точок прикладання сили, при яких характер втрати стійкості значно змінюється.

Ключові слова: полога конічна оболонка, комбіноване навантаження, ANSYS.

\title{
АНАЛИЗ ДЕФОРМИРОВАНИЯ И УСТОЙЧИВОСТИ ПОЛОГИХ ТОНКОСТЕННЫХ КОНИЧЕСКИХ ОБОЛОЧЕК ПРИ КОМБИНИРОВАННОЙ НАГРУЗКЕ РАВНОМЕРНЫМ ДАВЛЕНИЕМ И СКОНЦЕНТРИРОВАННОЙ В ТОЧКЕ СИЛОЙ В СРЕДЕ ПРОГРАММНОГО КОМПЛЕКСА ANSYS
}

\author{
${ }^{1}$ Бессмертный Я.О., аспирант, \\ yaroslavbessmertnyi@gmail.com, ORCID: 0000-0002-6884-0925 \\ ${ }^{1}$ Красовский В.Л., д.т.н. профессор, \\ stmehanika@gmail.com, ORCID: 0000-0003-0647-3880 \\ ${ }^{1}$ Приднепровская государственная академия строительства и архитектуры \\ ул. Чернышевского, 24a, г. Днепр, 49000, Украина
}

\begin{abstract}
Аннотация. Исследовано процесс деформирования и устойчивости пологих тонкостенных конических упругих оболочек при неоднородном напряженно-деформированном состоянии, обусловленном действием комбинированной нагрузки внешним нормальным однородным давлением и приложенной в точке силой при шарнирно-неподвижном закреплении края оболочки. Данный тип нагрузки в реальных условиях может соответствовать действию снежного покрова в определённом районе, согласно карты районирования территорий в ДБН В.1.2-2:2006 «Нагрузки и воздействия. Нормы проектирования» с изменением №1, и действию веса конструкции либо человека с оснасткой, что может находиться в определённый момент на поверхности конической оболочки.
\end{abstract}

Исследование деформирования и устойчивости пологих конических оболочек выполнено при помощи численного моделирования в среде программного комплекса ANSYS, эффективность применения которого для решения проблем разнообразного типа уже была подтверждена на международной арене. Модель пологой конической оболочки была создана с применением четырехугольного конечного элемента SHELL 281 с 8 узлами, что позволило получить не только симметричную относительно оси форму потери устойчивости, но и несимметричную. Во время численного моделирования проводилось два типа расчётов - линейной задачи потери устойчивости (бифуркации) с определением значения критического давления $\mathrm{q}_{\mathrm{cr}}$ и соответствующей ему формы потери устойчивости, и задачи геометрически нелинейного деформирования с определением значения предельного давления $\mathrm{q}_{\lim }$ и соответствующей ему формы потери устойчивости. Полученные значения несущей способности оболочек сравнивались с расчётными значениями нагрузок, которые возможно наблюдать на территории Украины.

Проведено анализ влияния каждого элемента комбинированной нагрузки на несущую способность оболочки в целом. В каждом случае расчёта именно равномерное нормальное внешнее давление было определяющим фактором потери несущей способности оболочки, тогда как изменение точки приложения силы влияла на величину критического и предельного давления при перемещении силы вдоль образующей конуса по направлению от вершины до основания оболочки. Проведено анализ влияния точки приложения силы на общую устойчивость оболочки, в частности на характер образования и распределения волн при бифуркации, их относительные величины и области распределения волн. Указаны области точек приложения силы, при которых характер потери устойчивости значительно меняется.

Ключевые слова: пологая коническая оболочка, комбинированная нагрузка, ANSYS.

Стаття надійшла до редакції 10.03.2020

Bulletin of Odessa State Academy of Civil Engineering and Architecture, 2020, no. 79, page 27-33 